Revista Iberoamericana, Vol. LXXX, Núm. 247, Abril-Junio 2014, 373-398

\title{
ENTRE LA FUNDACIÓN Y EL DERRUMBE: LA VIOLENCIA DEL TIEMPO DE MIGUEL GUTIÉRREZ
}

\author{
POR \\ María Elena Torre \\ Universidad Nacional del Sur
}

\section{MEMORIA Y VIOLENCIA}

En la estela de esa obra mayor que es la narrativa de José María Arguedas, en la que se puede leer que las heridas de la conquista no han cicatrizado, es posible ubicar la novela La violencia del tiempo (1991) de Miguel Gutiérrez. Formó parte en los años sesenta junto a Oswaldo Reynoso del grupo Narración ${ }^{1}$ integrado por narradores revolucionarios comprometidos con su pueblo que se presentaban con el deseo de una transformación a través de la acción y la obra creadora para hacer de "nuestro país un lugar donde todos puedan vivir como hombres", palabras que llevan la resonancia de "todas las sangres" (J. M. Arguedas).

Todavía no había comenzado "el tiempo del miedo", como llama el historiador Nelson Manrique (2002) a la violencia política instaurada con la "guerra interna”2 de los años ochenta entre el movimiento guerrillero Sendero Luminoso y las fuerzas militares y paramilitares, que dio lugar más tarde a alguna polémica entre intelectuales que defendían el socialismo y la lucha armada como posibles vías de cambio. Es el caso de Gutiérrez

\footnotetext{
1 El Grupo Narración reunió, entre 1966 y 1976 a importantes escritores peruanos de diferentes edades y militancia política, entre los que se cuentan Oswaldo Reynoso y Miguel Gutiérrez. Si bien la revista también llamada Narración tuvo solo tres números (1966, 1971 y 1974), sus propuestas acerca del realismo y la literatura popular enriquecieron el debate político y cultural. En el $\mathrm{N}^{\circ} 1$ decían: "Como hombres y narradores, seres sociales, luchamos por la transformación integral y completa de nuestra Patria. Queremos la instalación de un sistema socialista de trabajadores, porque comprendemos que es la única manera de hacer de nuestro país un lugar donde todos puedan vivir como hombres. Comprendemos, como narradores revolucionarios, comprometidos con su pueblo, que nuestra tarea es formar, a través de la acción y de la obra creadora, en la conciencia de las clases explotadas, la necesidad urgente de la Revolución. Por eso nuestra misión es aprender del pueblo, para poder escribir, sin equivocarnos, sobre la realidad nacional" (citado por Enríquez).

2 Esa denominación pertenece a los autores consultados así como, más estrictamente, "guerra senderista”, “guerra popular” o "guerra de guerrillas”, la referida a la lucha armada emprendida por SL.
} 
que, declarando su condición de "intelectual independiente" ${ }^{3}$ pero comprometido con el campo popular, revisa sus lecturas de Mao y de Mariátegui y abre un espacio para la autocrítica luego de la derrota del líder Abimael Guzmán y el costo que significó para el pueblo peruano y los propios combatientes el desarrollo de esa guerra; dicho testimonio nos permite señalar dos momentos en su proyecto estético-político y situar su novela La violencia del tiempo en un punto de inflexión -entre el compromiso y la revisión crítica- ya que, como declara el propio Gutiérrez, pertenece a una época en que “todas las producciones culturales, literarias y artísticas llevaban la huella de la cruenta y prolongada guerra interna que se desarrollaba en el territorio peruano” (Prólogo 7).

La configuración de un espacio simbólico donde emerge la violencia ${ }^{4}$ mítica o ritual, estatal o popular ha servido de marco para otros narradores como Alonso Cueto, Santiago Roncagliolo y Oswaldo Reynoso que forman parte del corpus seleccionado en trabajos anteriores. ${ }^{5}$ Un breve recorrido cronológico por ese corpus nos permite aprehender el modo en que poéticas y políticas de la representación interpretan e interpelan los procesos históricos. Memoria, violencia y escritura constituyen la ecuación que dibuja el escenario diverso desde el que es posible abordar las distintas perspectivas acerca de esa guerra interna.

En primer lugar, En octubre no hay milagros (1965) de Oswaldo Reynoso (escritor que ha concitado la atención de la crítica argentina ${ }^{6}$ a raíz de la publicación de su novela

3 Entre otras cosas aclara que asumió las ideas marxistas sin vínculo orgánico con ningún partido de la izquierda peruana y se refiere a los errores de la conducción de Abimael Guzmán a quien, sin embargo, ubica en la generación del 50, razón por la cual fue profundamente cuestionado. En el Prólogo de su libro de ensayos La generación del 50: un mundo dividido, 20 años después (2008), cuya primera edición es de 1988.

4 En este sentido, se han señalado tres concepciones generales de la violencia andina. Una interpretación histórica considera que la violencia se perpetúa debido a los conflictos étnicos, el faccionalismo político y el racismo como legado de la conquista y la colonización. Otra, más orientada hacia el presente, destaca el papel del estado y su uso de la violencia y la represión para forjar y perpetuar regímenes modernos de dominación. Una tercera visión, más centrada en las situaciones locales, toma como ejes de la violencia, el conflicto, el poder y la etnicidad presentes en la vida cotidiana y el trabajo en los Andes, lo que implicaría una cultura de la violencia en la región donde hasta hace poco prevalecía el gamonal (véase Klaren 8).

5 María Elena Torre, "Senderos de la narración: entre Alonso Cueto y Santiago Roncagliolo" en Actas del III Congreso Internacional "Transformaciones culturales: Debates de la teoría, la crítica y la lingüística” UBA, 2008, y a "Cuerpos de la violencia. Literatura y política en Alonso Cueto" en Actas de Orbis Tertius, 2009 y más recientemente "Narrar la violencia: En octubre no hay milagros de Oswaldo Reynoso” de próxima publicación en Actas del IV Congreso Internacional de Letras Transformaciones culturales. Debates de la teoría, la crítica y la lingüística en el Bicentenario. UBA, 2010.

6 "En octubre no hay milagros no fue un libro bien recibido por la crítica allá por mediados de los sesenta, y eso a pesar de que el primer libro de Reynoso, Los inocentes (1961), había sido celebrado nada menos que por José María Arguedas. En el influyente diario El Comercio, por ejemplo, el crítico José Miguel Oviedo

Revista Iberoamericana, Vol. LXXX, Núm. 247, Abril-Junio 2014, $373-398$
ISSN 0034-9631 (Impreso) 
en Argentina en el año 2009), en la que podemos leer una violencia emergente que se acompasa con los tiempos históricos: durante el pasaje por la ciudad de Lima con el telón de fondo de la procesión del Señor de los Milagros, Reynoso no sólo da a conocer el trabajo sobre la lengua oral popular en un juego intrincado de voces superpuestas sino que nos presenta un contrapunto entre la devoción religiosa y la furia de un pueblo sobre el que comenzaba a extenderse la violencia; se destaca en el final, la referencia de que ya en Puno se encontraban extremistas que "estaban armando a la indiada” (229). Es por esos años, concretamente 1964, que se ha señalado el surgimiento de Sendero Luminoso en Ayacucho y de su líder Abimael Guzmán. Carlos Ivan Degregori apunta que la extrema pobreza de la región agregada a la explotación terrateniente, la opresión y la discriminación étnica explican en parte la situación ayacuchana en la época anterior al surgimiento de Sendero Luminoso. ${ }^{7}$

escribió: 'Trataremos a su autor como lo que evidentemente es: un autor fascinado por la abyección, la morbosidad y la inmundicia en que se revuelca el hombre de esta misma pudibunda ciudad. Las relaciones sexuales son un camino de perfección en la perversidad: la sodomía no basta y se le injertan estímulos (drogas, bestialismo, alcohol). Hay páginas hediondas que deben arrojarse, sin más, a la basura y el autor es un marxista rabioso'. Extrañamente, entre los poquísimos defensores de En octubre no hay milagros -novela que, sin más, podemos considerar uno de los frescos urbanos más importantes de la literatura latinoamericana- fue Mario Vargas Llosa, quien hoy está a mundos de distancia de Reynoso en cuanto a sus opiniones políticas. Pero entonces supo ver la importancia de esta flor en la mugre: La novela de Reynoso no es pornografía ni es obscena, escribió en Expreso, 1966: ‘Es un libro de una crudeza fría y áspera como la realidad que la inspira y tiene los altos méritos -raros, entre nosotros- de la insolencia y de la ambición. El ha querido trazar un fresco verídico y múltiple de Lima, una radiografía horizontal y vertical de la ciudad, tal como lo hizo con México Carlos Fuentes en La región más transparente, y lo ha conseguido en gran parte"” (Enríquez).

Por otra parte, en una entrevista en la Revista Ñ realizada por Eduardo Ainbinder (2009) "Oswaldo Reynoso, El narrador de las cantinas”, Reynoso subraya su posición estética inseparable de una ética de la escritura.

7 Sin embargo, añade Degregori, que esto solo no explica la violencia que se desató en la región en 1980; entre los múltiples factores que marcan algunos momentos claves de la historia regional y conmocionan su estructura arcaica destaca la lucha por la educación y el papel fundamental que le cupo a la universidad: "La década de 1960 representó, pues un quiebre decisivo en la historia de Ayacucho. La universidad no sólo se convirtió en un canal de vinculación con los acontecimientos nacionales sino en un actor importante en la erosión del orden tradicional. Recordemos que la conmoción social que su presencia produjo, tuvo lugar en medio de la decadencia que vivía la región y sus clases dominantes tradicionales. Aprovechando ese cierto vacío de poder, ese momento decisivo en que la capa señorial terrateniente se batía en retirada y las nuevas capas burocráticas y comerciales ligadas a la expansión del aparato del estado todavía no habían llegado (lo harían recién en la década de 1970, durante el gobierno del general Velasco, aunque de alguna manera la propia universidad era la contradictoria avanzada de esa expansión), en la década de 1960 una nueva élite nucleada en la universidad y el FDPA (Frente del pueblo de Ayacucho) irrumpió por esos resquicios y se convirtió en verdadero contrapoder en Ayacucho, respetado y temido por el poder local tradicional e incluso por el poder central. Y en el corazón de ese contrapoder germinaba la “fracción roja'” (35).

Revista Iberoamericana, Vol. LXXX, Núm. 247, Abril-Junio 2014, $373-398$
ISSN 0034-9631 (Impreso) 
Por otro lado, La violencia del tiempo (1991) ${ }^{8}$ de Miguel Gutiérrez, motivo del presente trabajo, es una novela que recorre el largo camino que traza la memoria de la violencia fundadora (Ricoeur) desde la época de la Conquista e Independencia hasta los comienzos de las luchas sociales en los años sesenta, en la búsqueda de una comprensión a través de la historia de larga duración. Su perspectiva testimonial pone en juego una tensión constante entre sujeto y comunidad que subraya la memoria colectiva, con la intención de que otras voces además de la del yo se oigan en el texto.

Y por último, La hora azul (2005) de Alonso Cueto, en el marco de un relato intimista, trabaja desde el género de investigación para reconstruir una historia familiar vinculada con los enfrentamientos entre guerrilleros y militares en los ochenta, mientras que Santiago Roncagliolo logra, en Abril rojo (2006), un policial casi cinematográfico, que testimonia ese "tiempo del miedo", vinculado al movimiento Sendero Luminoso cuando decidió iniciar su guerra del pueblo en los olvidados departamentos de la zona sur de la sierra, donde la pobreza había profundizado la ira y el resentimiento de los campesinos. Con la llegada del Ejército a la región, la lucha armada librada por el grupo cruza un nuevo umbral de crueldad y comienza a golpear a las comunidades campesinas que constituyen sus "zonas guerrilleras".

Los textos de Cueto y Roncagliolo parecen estar planteando otra forma de la memoria, una memoria ejemplar al modo como la piensa Todorov (31-50), que pretende ser liberadora otorgando justicia al pasado; la fábula moral que se desprende del aprendizaje de vida del abogado Adrián Ormache en La hora azul así como la transformación de la figura del fiscal Félix Chacaltana en Abril rojo, parecen ir más allá de la reconstrucción de los hechos: abrir el recuerdo a la analogía y generalización para extraer una lección de la violencia a que condujo la lucha armada. Si una sacralización de la memoria vuelve insuperable el viejo acontecimiento, su uso ejemplar permite aprovechar las lecciones de las injusticias sufridas para luchar contra las que se producen en el presente. Se trata de conservar la memoria viva del pasado no para pedir reparación por el daño sino para estar alerta frente a situaciones nuevas y sin embargo, análogas.

Estas diferentes perspectivas de los textos narrativos sobre la violencia configuran modos de pensar la historia en un lenguaje que se articula desde "las ruinas del sentido". ${ }^{10}$

8 Las citas del texto se indicarán con número de tomo y página.

9 Según el informe de la Comisión de la Verdad y Reconciliación. Conclusiones generales del Informe Final de la CVR. Lima: Aprodeh, 2003... “el 75\% de las víctimas de la guerra de Sendero Luminoso fueron, según el informe, hablantes de quechua u otras lenguas nativas. Esto permite subrayar el importante hecho de que la guerra estalló y se libró sobre todo en la remota región de la altiplanicie del sur peruano-donde la pobreza es endémica y la mayoría de los habitantes pertenecen a etnias indígenas, particularmente en los departamentos Ayacucho, Huancavelica y Apurímac, el corazón del viejo imperio Inca” (Klaren 6).

10 De este modo describe Nelly Richard (32) el escenario chileno en su ensayo sobre la violencia. Señala que fueron dos los lenguajes que lograron sobreponerse a la desarticulación del sentido en la posdictadura: el

Revista Iberoamericana, Vol. LXXX, Núm. 247, Abril-Junio 2014, $373-398$
ISSN 0034-9631 (Impreso) 
Más allá de cifras y estadísticas plantean, a su modo, un debate para saber cuál de las memorias de los sucesos ha de prevalecer ya que, como señala Klaren "lo más perturbador es que aún hoy, ya derrotados, los restos de Sendero Luminoso se empeñan en presentarse y legitimarse ante una nueva generación de peruanos como herederos revolucionarios de la tradición radical de la historia del Perú” (41).

\section{DEL INTELECTUAL REVOLUCIONARIO AL NOVELISTA CRÍTICO}

Una breve reseña de algunas opiniones respecto del grupo Narración revela aspectos de la polémica que indicábamos al comienzo y da cuenta de la posición de Miguel Gutiérrez en el campo literario. Por un lado, el Grupo es visto como uno de los últimos proyectos del siglo xx de la estirpe a la que perteneció Amauta de José Carlos Mariátegui con su “invitación a la vida heroica” a alumbrar dentro de nosotros -según escribe David Abanto (2007) en el prólogo al estudio sobre el Grupo Narración- “el alma matinal” que sigue vigente, interpelándonos en este nuevo siglo. Destaca que el interés que ha vuelto a despertar el grupo Narración se debe a que junto a su actividad literaria ${ }^{11}$ se impusieron con una función de “conciencia ética” de la sociedad. Y añade: "Podrán haber mostrado equívocos, pero, aun así, no hay duda de que esa vigilancia y permanente cuestionamiento que ha ejercido sobre el funcionamiento de las instituciones y las acciones del gobierno es imprescindible en una democracia para que ésta no se corrompa y se vaya empobreciendo en la rutina”. Este prólogo de David Abanto titulado sugestivamente “Grupo Narración: la redención a través del compromiso”, refleja, aunque atenuada, una valoración de la figura del escritor comprometido y del intelectual revolucionario de amplia acción en el campo literario latinoamericano de los años sesenta y setenta que parece hoy desarticulada.

Por otro lado, y en oposición a esta valoración del Grupo, una fuerte reacción se ha despertado en algunas figuras renombradas. En este sentido, es significativa la respuesta de

discurso científico y la textualidad poética. Esta última emergió en la escena chilena del arte y la literatura de los ochenta a través de prácticas que en lugar de querer suturar las brechas dejadas por los vacíos de representación como la discursividad de las ciencias sociales, prefirieron "reestilizar cortes y fisuras, discontinuidades y estallidos” (33).

11 "Destaquemos su valoración de la tendencia realista, especialmente cuando no se contenta con solo mostrar, sino que formula interpretaciones y tantea soluciones orientadas al cambio revolucionario; mencionemos su identificación y admiración por los relatos realistas de César Vallejo, Ciro Alegría y Julián Huanay. La opción de Narración rescata, en consecuencia, mucho del realismo crítico y el realismo socialista, aunque comprende, consciente de la pobreza técnica y la visión maniquea de esta opción -eco del pro-vanguardismo auspiciado por Mariátegui-, la necesidad de asimilar las técnicas narrativas de la modernidad artística asumiendo creadoramente las técnicas de la nueva narrativa y la complejidad de lo real revelada por el neorrealismo urbano (Julio Ramón Ribeyro, Carlos Eduardo Zavaleta y Mario Vargas Llosa) y de ensayar nuevos caminos, ya sea asumiendo la tradición oral del pueblo, ya sea explorando el potencial literario de la crónica, el informe y la entrevista” (Abanto).

$\begin{array}{llllll}\text { Revista Iberoamericana, Vol. LXXX, Núm. 247, } & \text { Abril-Junio 2014, } & \text { 373-398 } \\ \text { ISSN 0034-9631 (Impreso) }\end{array}$ 
José Miguel Oviedo acerca de las causas por las que dicho Grupo no aparece mencionado en su reciente cuarto y último volumen de Historia de la literatura hispanoamericana (2001) en la que dice: "El problema es que cultivan un concepto de la literatura tan anticuado como su nostálgica visión de una China maoísta y de una 'guerra popular' que (afortunadamente) sólo existen en su imaginación, como parte de su petrificado canon personal” (3). Casi paralelamente y con relación a la reedición en 2008 del libro de ensayos de Miguel Gutiérrez La generación del 50: un mundo dividido, Iván Thays (joven narrador que también ha escrito sobre los años de violencia en Perú) ${ }^{12}$ ha hecho escuchar su voz en una polémica reseña titulada "Un artefacto literario anacrónico". La consideración de que Miguel Gutiérrez es un autor importante para el país por su ascendencia en varias promociones de escritores pasa desapercibida frente a los errores señalados por Thays que apuntan no sólo a las reiteradas alusiones a Sendero, Guzmán y la "lucha popular” sino también a los criterios de su narrativa que ve en los personajes, antes que individuos, alegorías de clases sociales o las contradicciones de Gutiérrez a quien no le concede su pasaje a una "nueva conciencia”. Sin embargo, y contrariamente a este enfoque, la reedición de los ensayos de Gutiérrez ha sido vista como un "testimonio del tipo de debates y posturas de nuestros intelectuales frente a una de las peores crisis vividas en la historia del Perú” (Agreda 1).

Estas opiniones críticas de las que he registrado sus acentos polémicos parecen no advertir un desplazamiento en la postura política de Gutiérrez desde sus primeros años de intelectual revolucionario a su revisión crítica en una segunda etapa, en la que no sólo ajusta su postura política a la historia vivida en su país, sino también, como veremos, da un giro al realismo socialista incorporando una perspectiva de vanguardia articulada con una nueva mirada sobre el indigenismo que pone en crisis la identidad andina. ${ }^{13}$ Me interesa poner en foco algunas consideraciones del prólogo ya mencionado de sus ensayos, en el que advertimos algo de ese desplazamiento que se revelará como tensión propia del lenguaje narrativo en la novela que analizaremos.

Ya en la primera edición de 1988, su libro La generación del 50: un mundo dividido, según consigna Gutiérrez, dio lugar a rechazos y adhesiones polémicas entre los grupos de izquierda y de derecha por la crítica a figuras prominentes del campo intelectual y la consideración de Abimael Guzmán dentro de esa generación. En la reedición del 2008, Gutiérrez no sólo se refiere al silencio (y paradójicamente al interés creciente que fue despertando) al que fue confinado el libro en su momento, sino que también

12 Su novela Un lugar llamado Oreja de Perro (Anagrama 2008) aborda las consecuencias del terrorismo de Estado en la trama social.

${ }^{13} \mathrm{Al}$ respecto Gutiérrez aclara que evita el término "indigenismo" o "indígena" puesto que considera que es un componente más de la peruanidad y en cambio, prefiere hablar de "mestizaje", de la complejidad de la condición mestiza en un país que se ha transformado en multinacional, multiétnico (Da Gama 75).

Revista Iberoamericana, Vol. LXXX, Núm. 247, Abril-Junio 2014, $373-398$
ISSN 0034-9631 (Impreso) 
sienta su posición respecto del líder senderista, a partir del comentario de un folleto del FER (Frente Estudiantil Revolucionario) que circuló por los ambientes universitarios de la época con el lema Por el sendero luminoso de José Carlos Mariátegui, de donde proviene el nombre de la organización guerrillera. Gutiérrez hace un análisis crítico de ese texto y de lo que luego se llamó el "Pensamiento Gonzalo" en el que sobresale no solo un "Mariátegui unilateral, ortodoxo, dogmático", sino también la referencia a la "contundente derrota de la línea ideológico-política". ${ }^{14}$ Digamos, por otra parte, que además de reunir en sus páginas a poetas, narradores y pensadores sociales, Gutiérrez aclara y revisa "la parte que mayores enojos y malentendidos suscitó", lo que según la fórmula sartreana se denominó "el compromiso social del escritor" porque tuvo especial cuidado en no descalificar estéticamente una obra por las concepciones ideológicas de su autor lo que -insiste Gutiérrez- ubica su trabajo sobre la generación del 50 en el territorio del debate. Pese a ser un libro controversial Gutiérrez justifica la reedición deslizando su autocrítica: "algunos de cuyos planteamientos de tipo político han sido desmentidos de manera implacable por la propia realidad del país” (Prólogo 6).

Su caracterización de este ensayo como un discurso libre que navega entre la literatura, la filosofía y la ciencia, con una estructura dúctil en la que tienen cabida el relato, el testimonio, la crónica y el diálogo, escrito durante la época en que también escribía La violencia del tiempo, abre la entrada al texto de la novela, dado que no sólo nos encontramos con una hibridación de discursos -entre otros los mencionados para el ensayo-, sino también con una sinuosa complejidad de la voz narrativa.

\section{Mito y ARChIVo}

La novela se puede leer como una indagación de la identidad en relación con la violencia fundadora: una saga familiar sobre el telón de fondo de la historia de una comunidad que almacena en la memoria acontecimientos violentos como heridas reales o simbólicas, llega hasta la Conquista y las luchas por la emancipación, con referencias a la Comuna de París, los levantamientos anarquistas en Barcelona y la Guerra con Chile, sostenida por la voz de un narrador que sobre el final hace su balance: "He logrado fabular la historia de una herida que a todos nos alcanza y la historia de la vindicación primitiva y bárbara y el rencor inextinguible, junto al itinerario de vidas que arrastran consigo los furores de la Historia” (La videncia III 307).

${ }^{18}$ Como explica a continuación: "Pasando por alto las reiteradas propuestas de Mariátegui y de Mao, SL, con la guía de Guzmán, desarrolló una política autoritaria, hostil (casi de desprecio) a los intelectuales, línea política que se resumía en una cita de Engels, sacada por lo demás fuera de contexto, según la cual 'los intelectuales conformaban un montón de colosal basura’. Esto espantó a los intelectuales y canceló la posibilidad del surgimiento de un movimiento renovador y democrático en la cultura y el arte” (Gutiérrez, Prólogo 4).

\begin{tabular}{l} 
Revista Iberoamericana, Vol. LXXX, Núm. 247, Abril-Junio 2014, $373-398$ \\
\hline ISSN 0034-9631 (Impreso)
\end{tabular} 
El Congará de los Villar en la zona de Piura se recorta en el texto, al modo de otras novelas latinoamericanas, con su historia y sus mitos. No es casual que sobre el final de la novela, el narrador-protagonista Martín Villar arda en "deseos de meterle el diente" (III 263) a Cien años de soledad recibida a través de un amigo (en coincidencia temporal con su publicación, 1967). Podríamos decir entonces que es "casi” (Gutiérrez, "Sobre el rencor” 275) una novela en la que, a lo largo de mil páginas, dialogan en contrapunto el ensayo, el relato y el testimonio; que toma la forma de una ficción del Archivo con la preocupación por los orígenes, y quiere ser tanto el relato de la historia del Perú como de la construcción del texto.

Así y siguiendo la caracterización de González Echevarría (50) es posible encontrar los rasgos de la novela de Archivo con los elementos mediadores a través de los cuales se narró, el historiador interno que lee los textos, los interpreta y los escribe y el manuscrito inconcluso que se trata de completar. En este sentido, podemos considerar como elementos mediadores los acontecimientos históricos que enmarcan los hechos que se narran, las incontables fuentes filosóficas que se mencionan, los Diarios y la Geografía física de la región piurana del personaje del Dr. González, así como las cartas y testimonios de algunos personajes que vivieron otros contextos históricos y los archivos de retratos fotográficos. Por otra parte, Martín Villar no sólo es el historiador interno que lee los textos y los interpreta, sino que este "pichón de historiador", como se nombra a sí mismo (I 132), instala una discusión acerca de distintas concepciones historiográficas entre un profesor tradicionalista continuador de la obra de José Riva Agüero ${ }^{15}$ y su propia inclinación por las fuentes orales: “el secreto familiar que se transmitía por vía femenina y el rumor persistió a través de los siglos” (I 200). Por último, tenemos el manuscrito inconcluso en los cuadernos que le legara su padre, a partir de los cuales Martín Villar va construyendo el texto narrativo, con innumerables variaciones y referencias a una poética de la novela en tensión constante con la imposibilidad de concluirla.

${ }^{15}$ Es muy elocuente la imagen de los años de formación de Martín Villar, cuando el narrador relata (con una fluctuación entre la tercera y primera persona como en otros pasajes) las clases de historia con el joven profesor Eric Dutúrpuru Paz-Soldán quien, como su maestro Gandamo de la Romaña, y de acuerdo con José De la Riva Agüero se empeñaban en demostrar la pureza de la sangre de los conquistadores. Este "imposible mestizo" a los ojos de Dutúrpuru exige se le conceda la palabra mientras se desarrolla un debate acerca de la rivalidad entre Pizarro y Almagro. "Se había hecho un silencio y todas las miradas convergieron en Martín Villar: un becario seguramente: un amorfo -como denominaban los retoños de la vieja aristocracia y los advenedizos y nuevos ricos a los alumnos de piel modesta, la mayoría ex seminaristas pero ligados a la iglesia que subvencionaba sus estudios- e hicieron un gran esfuerzo para no soltar la carcajada por aquel terno de confección silvestre y de inevitable color azul fúnebre y corbata ordinaria que desarmonizaba de manera intolerable con el color del traje. [...] Hice un esfuerzo por calmarme, mi yo se había difuminado, mi voz la sentía ajena, entonces me dije que mi voz no me pertenecía, que era un conglomerado de voces y por primera vez me consideré como parte de una comunidad” (I 119-121). Unas páginas más adelante el narrador vuelve con la mención del terno azul en un verso de Vallejo, poeta que custodia el proyecto creador de Gutiérrez ya desde el epígrafe.

Revista Iberoamericana, Vol. LXXX, Núm. 247,
ISSN 0034-9631 (Impreso) 
La memoria “atroz y fascinante” (II 21) se presenta para el narrador como un recinto sin límites de donde fluyen recuerdos, rostros, voces, sueños en una revelación a través de imágenes turbulentas que alcanzan la dimensión del mito, luego de escuchar "la voz sacramental del cactus dorado” (II 10). Justamente el capítulo V, “El cactus dorado”, que inicia el tomo II de la novela (uno de los más extensos) hace de bisagra, de pasaje en la extensa narración. Por un lado, en una condensación del tiempo a través de las visiones, el protagonista recorre el pasado y tiene la anticipación de hechos futuros y, por otro, se abren diversas líneas narrativas en forma de cartas o crónicas que proyectan la memoria colectiva de la violencia, en los acontecimientos que aparecerán más desarrollados: la comuna de París y los levantamientos anarquistas en Barcelona, con el trasfondo siempre presente de la saga familiar y sus vínculos con otros hechos de violencia en tierras del Perú, la Guerra del Pacífico ${ }^{16}$ y el levantamiento de los comuneros chalacos en la zona piurana.

En ese episodio, Martín Villar recibe de un anciano de la región “la pócima amarga extraída del cactus dorado de sus antepasados”(11) que le permite batallar con la memoria y la invención para recuperar los instantes perdidos a través de visiones que se remontan al fundador del “amargo linaje” de los Villar y la historia de esa "raza perversa” como la nombró Santos Villar, su abuelo, pasando por su propio nacimiento. Sin embargo, el curso temporal se ve alterado y, a modo de oráculo, se proyectan imágenes del porvenir, de su llegada a Lima y su militancia breve en los sesenta junto a Deyanira Uribarri, visiones que inmediatamente y en un breve apartado, "La guerra y la otra violencia”, se pondrán en contrapunto con la violencia que asoló a la región durante la ocupación chilena. A través de la estrategia narrativa de las visiones se opera el desplazamiento hacia el mito del origen, otro modo de narrar la historia y ahondar en lo que se llamará “El agravio”, historia sin redención posible de los sobrevivientes de su sangre sobre la que el protagonista se interroga: “¿Y para esta vergüenza se fundó esta sangre?” (301). La sangre, el linaje y un destino cuyo blasón será la figura de su antepasado Miguel Villar, un vagabundo, un forajido que Fernando VII envió a aplastar la revolución americana, con un sable y una pistola, testimonio no de la victoria sino de la derrota. Con estos indicios y en coincidencia con lo señalado por Peter Elmore (638) es posible ver en esta saga una “réplica perversa” de lo que sería un relato fundacional en el sentido tradicionalista, sobre el que se opera un descentramiento del modelo prestigioso, ya que

16 “La Guerra del Pacífico (Chile/Perú-Bolivia) tomará en la sierra peruana a menudo el aspecto de un enfrentamiento abierto entre latifundistas colaboracionistas y comunidades indígenas [...] La victoria de los chilenos y el fortalecimiento de los sectores oligárquicos crea condiciones muy favorables para el despojo de las tierras comunales por parte de los latifundistas [...] Numerosas serán, entonces, las rebeliones indígenas en la zona andina. [...] A partir de 1900, aproximadamente, surgirán una serie de movimientos mesiánicos que exigen, según algunos, la restauración del Tawantinsuyu. Tales movimientos suponen una coyuntura nueva caracterizada por la solidaridad pro-indígena de ciertos núcleos de intelectuales” (Lienhard 120; énfasis mío).

Revista Iberoamericana, Vol. LXXX, Núm. 247, Abril-Junio 2014, $373-398$
ISSN 2154-4794 (Electrónico) 
no se trata de figuras heroicas ni de aristocracia de sangre sino de lo que para Martin Villar es la historia de los “desheredados de la tierra” (III 12).

Un modo frecuente de articular el relato es a través de las preguntas, con el propósito tal vez de acrecentar la incertidumbre acerca de los hechos que se van narrando o como una estrategia para la comprensión de estos. Una y otra vez las preguntas aparecerán hasta el final referidas no sólo al problema de la identidad, sino también a cuestiones políticas. Enunciadas por distintos personajes, son interrogantes formulados por un narrador-investigador que utiliza ese recurso como una necesidad de escribir no solo para reconstruir los hechos sino para comprender y explicar. En cuanto a la propia historia familiar, aparecerá "la única pregunta que había contado en su vida y para la que no había hallado respuesta” (III 19) que, formulada por su bisabuelo, seguirá atormentando a Martín Villar: "Pero ¿quién era él? ¿Cuál era su casta, su sangre?” (III 19) ${ }^{17}$ La historia de un padre ausente marca la trayectoria de vida del protagonista que en la lectura de Peter Elmore cobra especial significación, ya que no solo la refiere al estigma de la ilegitimidad de los hijos mestizos sino que ve en este aspecto un vínculo intertextual con Pedro Páramo de Rulfo, y a Congará bajo el diseño de Comala (639).

Las cuestiones de orden político también aparecen puntuadas por preguntas en función de los hechos que se narran: “¿Qué es un republicano? ¿Qué es un socialista? (II 177) y más adelante ¿Qué es el pueblo? (III 77) ¿Qué era la patria? (III 145) ¿Qué clase de guerra es esta? (III 153) ¿Qué enseñanzas sacaste de la guerra? ¿Qué descubrimiento acerca de tu patria, del especimen llamado "hombre", de ti mismo? (III 164), y el archivo comienza a desplegarse como salido del baúl, con las pertenencias del abuelo, que Martín abre y cataloga estremecido por un temblor, a poco de iniciado el relato (I 51).

Este narrador-investigador, en su breve paso por la vida universitaria de la que se aleja desencantado, relata sus últimas semanas en Lima en coincidencia con el triunfo de la revolución cubana y su acercamiento "a la juvenil Deyanira Uribarri con su fresca y pura fe en el socialismo” (II 66). Es así como se propone "entender el problema de las revoluciones que ahora agitaban las zonas atrasadas de la Tierra” y decide librar su propia lucha en la Hemeroteca de la Biblioteca Nacional que se convierte en su "cuartel general”. A modo de un relato de investigación comienzan sus pesquisas para encontrar la huella de un aventurero, Baumant de Metz, que había llegado a Piura con la Gran Idea de la Comuna de París, mientras que la reflexión acerca de su propia escritura agrega a la narración un matiz de desconfianza: "y el pichón de ¿escritor? ¿memorialista? (o qué diablos seré, Deyanira?)” (II 69). El volverse hacia sí mismo del narrador que va siguiendo el proceso de construcción del texto, parece mostrar que "el acto de escritura

\footnotetext{
${ }^{17}$ Horst Nitschak señala que la pregunta inicial “¿Quién castró al gran padrillo?” ligada a la búsqueda de la escena originaria, significa la pregunta "por la verdad, por lo real” que desencadena sucesivas preguntas no resueltas y revela la imposibilidad de "diferenciar claramente entre agresores y víctimas” (133).
}

\footnotetext{
Revista Iberoamericana, Vol. LXXX, Núm. 247, Abril-Junio 2014, 373-398 ISSN 0034-9631 (Impreso) ISSN 2154-4794 (Electrónico)
} 
está atrapado en una lucha mítica de profundas raíces que le niega constantemente la autoridad para generar y contener conocimiento acerca del otro", "una forma de desarticular la mediación a través de la cual se narra América Latina” (González Echevarría 57). El narrador recurre entonces a modalidades narrativas importantes de la ficción del Archivo que, como dijimos, serán las cartas y la crónica. ${ }^{18}$

La reconstrucción de acontecimientos históricos que el protagonista intenta conocer y comprender se ofrece a través de un material documental fragmentario que aparece por vía indirecta a través de extensas cartas (a modo de diálogos) como las del personaje Baumant de Metz (embarcado en 1871 para América y su llegada a Piura) que adjunta testimonios con datos, fechas, libros y periódicos (II 152) referidos a los combates de la Comuna de París, o la carta de un comunero (capítulo "Desde las barricadas”) quien confiesa que se plegó a la lucha "impulsado por ver a tantas muchachas obreras con el fusil en las manos”. Una de las cartas está dirigida a Augusto González Urrutia, el Dr. González, amigo del padre del narrador, figura que adquiere mayor relieve en el epílogo de la novela. La estrategia narrativa permite no sólo que el personaje de Metz relate su experiencia en los combates de la llamada "semana sangrienta" con datos y nombres que la ilustran acabadamente y otros ficcionales, con anécdotas que sirven de base, sino también la puesta en escena de "la violencia social y política, que es la que se ejerció y estuvo en disputa durante los días de la Comuna” (II 151), con abundantes citas teóricas de Proudhon y Marx entre otros y referencias a la filosofía de Spinoza (filósofo favorito del Dr. González). El relato de estos hechos ha servido al narrador para introducirse en la rebelión de los comuneros de San Francisco de Chalaco ${ }^{19}$ supuestamente imbuidos por el ideario de Baumant de Metz y también en el “odio al chileno” a raíz de la Guerra del Pacífico, y para recordar a los compañeros del colegio de su infancia "con sus vanos sueños de seguir la carrera de las armas para vengar aquella intolerable derrota” (II 124).

Del mismo modo, la extensa narración de la experiencia del Padre Azcárate junto a los anarquistas en los levantamientos de Barcelona de 1909, su lectura de Marx y de San Agustín servirá para recordar (ya en territorio de Piura adonde llega posteriormente) que, por medio de parábolas, Cristo afirmó que había traído al mundo la guerra y no la

${ }_{18}$ Ángel Rama ha señalado la importancia de la compleja red de comunicaciones alrededor de las cartas en la vida colonial, "una suerte de cordón umbilical escriturario"; el género literario más encumbrado, junto con las relaciones y crónicas (Ciudad letrada 47).

19 De un documento titulado "La toma de Piura por los chalacos: un acontecimiento político y social" del Lic. José Miguel Godos Curay, obtuvimos la siguiente información:

"Miguel Maticorena Estrada, encuentra en la comuna chalaca un eco de la comuna parisina. Se buscaba formar un solo cuerpo de nación frente a chilenos e iglesistas en un Perú sacudido por una grave crisis. Hay una transición social de una sociedad de castas a una sociedad de clases. El tema bien ha servido de inspiración a escritores como Miguel Gutiérrez que sigue la huella de Baumen de Metz un desconocido comunalista que vino hacia América desatada la gran persecución y que se asentó por las tierras de Chalaco pero del que no se tiene datos históricos fehacientes” (Godos Curay).

Revista Iberoamericana, Vol. LXXX, Núm. 247, Abril-Junio 2014, $373-398$
ISSN 2154-4794 (Electrónico) 
paz y que "en el corazón humano existe inscrita una ley natural que justifica la rebelión allí donde existe opresión y pobreza” (III 324). Dos capítulos dedicados a la historia del Padre Azcárate relatan sus disidencias con grupos más ortodoxos de la Iglesia, una vez salido del seminario y emprendida su labor social con la prédica del evangelio que justificaba la lucha contra las tiranías y las desigualdades sociales. Estos episodios “encontrados en los papeles personales del Dr. González” (III 340) que el narrador refiere a modo de crónica, entre el testimonio y la ficción, toman una significación adicional al poner de relieve los meandros de una conciencia atormentada a quien se le adjudica estos interrogantes: ¿Quién soy? ¿Quién fui? ¿A quién he servido? El narrador por detrás, parece identificarse con el título dado al capítulo "Una perenne agonía", seguramente tomado de uno de los libros que el mismo Padre Azcárate ha comprado en su paso por Barcelona, La agonía del cristianismo de Miguel de Unamuno, agonía que se prolongará aun estando ya en Piura al conocer la noticia, en marzo de 1939, de la sangrienta derrota del Frente Popular Español.

Estas y otras incontables fuentes del Archivo pretenden cruzar fronteras para ir trazando esa "violencia del tiempo" y sus vínculos con el más cercano presente del narrador ligado a la emergencia de las "luchas sociales del Perú que comienzan a apasionarte” (III 307), como le dice Martín Villar a Zoila Chira su compañera, ya convertida en maestra rural e interesada en las reivindicaciones gremiales. Algunos de los diálogos con Zoila Chira se desarrollan en la tierra de sus antepasados, las dunas de El Conchal, ante la vista del vichayo, árbol tutelar de la casa de los Villar, escenario luego arrasado por el desborde del río pero que guarda la memoria de la violencia que ejercía el bisabuelo con sus hijos así como su pasión por la pelea de gallos. En el capítulo IX, "El agravio", con ese escenario, el narrador evoca las voces de sus antepasados al modo de un guión teatral con entradas e indicaciones escénicas entre paréntesis: otra estrategia narrativa que permite distanciar y variar la historia que se viene contando. Se destaca aquí un personaje, la maestra Domitila Diéguez, procedente de una familia de maestros, discípulos de Simón Rodríguez, quien se convierte en "una suerte de conciencia acusadora” (339). En esta ocasión, el narrador cuenta un fragmento de la historia de crueldad y violencia del blanco Odar Benalcázar con el bisabuelo Cruz Villar, ante quien ella intercede. Interesa esta escena no solo porque a la vista de todo el pueblo Cruz Villar debe aceptar su derrota, sino por la mención de "ese loco magnífico"20 de Simón Rodríguez al lado de los ideales de Domitila Diéguez y a renglón seguido la opinión de un testigo de la escena, el francés Boulanger, quien se refiere a ella como la

${ }^{20}$ Ya en el capítulo III, “El viento y la memoria”, luego del texto del epitafio de Domitila Diéguez, aparece el nombre de Simón Rodríguez y el recuerdo de los árboles que plantó en la plaza de Congará. La figura de este educador venezolano y su estadía en el Perú cobran relevancia en la memoria del narrador ficcional.

Revista Iberoamericana, Vol. LXXX, Núm. 247, Abril-Junio 2014, $373-398$
ISSN 0034-9631 (Impreso) 
barbarie. ${ }^{21}$ Este capítulo resulta altamente significativo no sólo por la intervención de los testigos indios, la "querella de los ancianos", sobre la que el narrador se interroga (añadiendo una vez más el matiz conjetural a la construcción del texto) si se trata de una “comedia”, una "farsa pública” o un "auto sacramental”, sino también porque la figura del educador Simón Rodríguez , uno de los hombres prominentes que aparecen en el texto, y la mención de la barbarie (antes "la contienda entre civilización y barbarie" [II 238]) permite pensar en un debate entre los dos linajes, las armas y las letras, que podría seguirse en la propia historia de vida del narrador ficcional. ${ }^{22}$ Por otra parte, el escarnio público sufrido por su bisabuelo y liderado por Benalcázar, que una y otra vez se menciona como el "agravio" mantenido en secreto en la familia, tiene origen en el episodio fundamental que desencadena la historia y que la atraviesa como un eje de sentido hasta el final de la novela: la deshonra de la tía Primorosa y el castigo que padeciera su bisabuelo.

Tal como en otras novelas de archivo, el inicio de la historia es un relato de violencia e incesto que se constituye en un mito: la entrega o "subastación” de Primorosa Villar de 15 años a Odar Benalcázar por parte de su padre (bisabuelo de Martín), la decisión de ella de quemar el engendro de esa unión "reducido a un puñado de ceniza pestilente" (I 125), su abominación de la sangre de los Villar, su huida y temprana separación del

${ }^{21}$ Conocimos a François Boulanger a través de otra fuente indirecta, la novela Un pájaro del mal que el narrador atribuye al escritor-periodista Sansón Carrasco en el capítulo VII. Curiosamente aparecen al pie dos Notas de Autor (235), las únicas del texto, que con ironía refieren al "estilo presuntuoso" de Martín Villar para describir las reescrituras que ha sufrido el estilo "tumultuoso" del "combativo escritor" Carrasco y su "noveleta [...] mezcla de crónica, reportaje, de memorias, de reflexiones” y discute un presunto influjo de Zola en dicho escritor. La estrategia no acaba aquí ya que, además, entre las razones del fracaso de dicha noveleta menciona que: "El repudio moral que le suscita el infame François Boulanger convierte el relato en una banal tesis en que se dilucida la contienda entre civilización y barbarie [...]... a diferencia de sus coetáneos regionalistas, Sansón Carrasco exalta como valor la barbarie, representada por el impetuoso Odar Benalcázar contra la civilización simbolizada por François Boulanger” (238). Con esta "réplica perversa" (tomando la expresión de Elmore) Gutiérrez agrega otros indicios que otorgan densidad al proceso de construcción del relato. En la descripción de la estructura del texto de Carrasco el narrador luego de repetir el comienzo del texto “¿Quién es, quién fue, quién era François Boulanger de Chorie? " consigna que "propone un enigma y pretende crear un clima de misterio y suspenso mediante el recurso de reiterar con diferentes variantes la interrogación: esta, como una letanía, se escucha por los más diversos ambientes de Piura...” Se trata ni más ni menos que de la estrategia mencionada del propio Gutiérrez y que se añade al hecho de que Carrasco además de haber cuestionado "la razón de ser de la literatura” piensa que su novela merecía la destrucción, como ocurre con la propia novela que analizamos. En éste capítulo, como en el I (84) cuando imagina una polémica entre Carrasco y el Ciego Orejuela el "bardo de la tierra piurana” (otra figura clásica), Gutiérrez crea una perspectiva crítica referida a la objetividad y la autenticidad de las fuentes de la historia, que revierte inevitablemente en el propio texto que vamos leyendo y parece insistir en "la índole conjetural de la historia, porque nunca se sabrá la verdad de los hechos” (I 193; énfasis mío).

22 Es esta la perspectiva de lectura de Peter Elmore (2007) quien ha señalado "la sangre y la letra” como las dos matrices de filiación de la historia familiar de los Villar y por extensión, de la historia nacional. ISSN 0034-9631 (Impreso) 
amor de su hermano Inocencio "en yunta contra el destino" (I 230), es una secuencia narrativa que con sus lagunas, silencios y contradicciones, condensa la violencia que se remonta a los antepasados del ex soldado godo Miguel Francisco Villar y la india Sacramento Chira y se perpetúa en la historia más cercana: la de Martín con Zoila Chira y su negativa a concebir hijos con ella, episodio que se enlaza con el mito de la identidad mestiza.

En este punto resulta pertinente la mirada crítica de Antonio Cornejo Polar quien en su artículo "Literatura peruana e identidad nacional: tres décadas confusas" de 1995, advierte que la literatura comienza a dar razones tentativas de la desestructuración que se percibe en la vida nacional, construyendo figuras polimorfas de la nacionalidad, mezclas que en algún momento pensó que remitían a la idea de mestizaje pero, subraya a continuación, la identidad fuerte de mestizaje también está en crisis. Y añade: "la imagen de Garcilaso ha cambiado. Ya no se le ve como una figura armoniosa que ha superado el enfrentamiento de sus dos linajes; se le ve más bien, como un ser angustiado, lleno de conflictos no resueltos: tiene un deseo de armonía pero esa armonía es imposible” (299). A continuación Cornejo Polar se refiere a La violencia del tiempo de Gutiérrez como una excelente novela, "casi milagrosa” acota y en un paréntesis: "escribir en el Perú de hoy una novela de tres tomos es francamente asombroso" (299). En ella, el narrador hace la más cruda denuncia del mestizaje entendido como maldición ya que la historia que se cuenta se remonta a la violación de la madre primordial por el conquistador, tratándose, concluye, de una "insólita novela antimestiza”. Con esta calificación, Cornejo Polar refiere al tramo final de la novela cuando el personaje Martín Villar embaraza a su compañera india y la obliga a abortar, hecho que es interpretado como la necesidad de acabar con un linaje "maldito". Interesa esta lectura de Cornejo porque dio lugar a la réplica por parte de Gutiérrez (en Da Gama 78) en cuanto a que no es exacto que su novela sea una recusación del mestizaje, sino más bien una problematización de "la condición mestiza" por ser el producto de la conquista y colonización, y constituir entonces una "zona de contradicciones, conflictos, rencores y furores” en la que además del componente de la raza y la sangre, intervienen factores históricos, sociales, económicos, morales y sicológicos que constituyen las particularidades del mestizaje en el Perú y se erige en una suerte de destino para los individuos y las colectividades. La diferencia de grado que va de la palabra "maldición" (usada por Cornejo) ${ }^{23}$ a las de "destino" agravado por el "rencor" que emplea Gutiérrez, no parece sustancial frente a las coincidencias fundamentales entre ambos, acerca de la conflictividad que ha adquirido la identidad mestiza alejada del "gran mito salvador" [...] "que producía una imagen conciliadora, homogénea, y desproblematizada de la nación” (Cornejo Polar 298).

${ }^{23}$ Es posible que Cornejo Polar haya tomado la palabra del propio texto. Ubicamos una referencia vinculada, en este caso, al Dr. González... "le había sido negada la paternidad, el don de legar una sangre y de asegurar la continuidad de un linaje no condenado ni maldito” (III 364; énfasis mío).

ISSN 0034-9631 (Impreso) 
La posibilidad de plantear la identidad como una zona de contradicciones y conflictos acerca ambas perspectivas y pone a la vista el debate actual sobre identidad y violencia ya que, como señala Amartya Sen: "La ilusión del destino, en especial acerca de una u otra identidad particular, alimenta la violencia en el mundo tanto mediante omisiones como hechos” (12).

LA ESCRITURA Y LA VIDA

¿dónde debiera comenzar esta historia? [...] ¿En la vida o en el arte? (III 173)

Indagar un poco más en otros fragmentos de la historia nos permite ahondar en la problemática de la identidad desplazándonos desde la violencia fundadora y ritual que atraviesa toda la novela hasta la violencia desatada por la guerra interna de los años ochenta que sobrevuela por el texto. Para ello centramos la atención en la dedicatoria de la novela que dice:

Escrita por Martín Villar para perpetuar la imagen de Deyanira Uribarri al desparecer él mismo de las páginas de esta novela no pudo saber de la muerte de su querida amiga, a la que durante años evocó como una bella y justiciera Antígona. Por eso, interpretando el espíritu de Martín Villar, el autor rinde homenaje a la gloriosa memoria de Deyanira Uribarri, muerta en el combate por sus ideales de justicia y dignidad humana.

Frente a este homenaje en el que la figura de Deyanira enlaza la voz del protagonista con la del autor no podemos dejar de recurrir a los testimonios del propio Gutiérrez (2008:7) que refieren a su situación "contradictoria y vulnerable” en un alto de la escritura de la novela "con un trasfondo de dinamitazos, descargas de los FAL y el desplazamiento de los tanques del ejército", "porque seres muy queridos habían optado por lo que Sendero denominaba Guerra Popular” (Prólogo 7).

Ligada a ese presente urgente de la vivencia, Deyanira Uribarri Osejo también aparece como personaje de la novela. Perteneciente a un linaje encumbrado de la región andina ("gamonales explotadores y crueles" de los que reniega [I 213]) es una de las lectoras de los manuscritos de Martín Villar (la otra será Zoila Chira) en un encuentro breve de la Lima siniestra, evocado luego por el narrador como la "dicha fugaz que iluminará para siempre su vida” (II 51). En esos días que pasaron juntos mantienen un diálogo acerca de la escritura de la novela en el que, luego de conocer la historia de la tía Primorosa ("la perra que devoró a sus crías" [170]), la memoria de ese ultraje, Deyanira expresa su pensamiento respecto de la condición de la mujer. Es significativa la secuencia del texto en la que Martín en su regreso a Congará desde Lima, con la intención de reconstruir los pasajes de la historia que está escribiendo, recuerda aquellas

\footnotetext{
Revista Iberoamericana, Vol. LXXX, Núm. 247, Abril-Junio 2014, 373-398 ISSN 0034-9631 (Impreso) ISSN 2154-4794 (Electrónico)
} 
palabras de Deyanira: "Las mujeres no deben parir. Antes de quedar preñada, me haría extirpar los ovarios”, y a continuación otras de Zoila Chira “¿En tan poca cosa me tiene - maestro Martín, que no me deja parir de usted?” (I 170). Este nudo de la historia plantea interrogantes que abren posibles significados. Si bien, como interpretaba Cornejo Polar, refiere a la negativa a continuar el linaje mestizo vivido conflictivamente como una herida, el "agravio" sufrido en el devenir de la historia familiar, es posible también pensar esta cuestión en relación con el contexto dramático de la escritura de la novela al que se refiere Gutiérrez y el incierto futuro. De este modo, lo dicho por Deyanira se podría vincular con el rigor del pensamiento militante de una combatiente en la guerra popular, ${ }^{24}$ y el escepticismo que pudo embargar a quien estuvo a su lado, vivió la esperanza del advenimiento del hombre nuevo ${ }^{25}$ y la consiguiente derrota de esa lucha. No es casual que este personaje evocado con dolor desde el comienzo hasta el final por Martín Villar ("historia que escribo pensando en ti, pensando en ti, Deyanira” [II 302]), sea quien le da consejos sobre su proyecto de escritura en el sentido de que abandone la decadencia del pasado y se dedique a lo que simboliza el futuro, que reivindique a su propia gente ("la vida de los descendientes de la india Sacramento Chira vale más que cualquiera de los Benalcázar León”) y que escriba "sobre nuestra realidad social” (I 213). Vedada la posibilidad de engendrar descendencia la figura femenina se vincula así a la producción de la escritura. ${ }^{26}$

En otro pasaje se nos revela la conciencia desgarrada del narrador, quien le confiesa a Zoila Chira que "hubo un tiempo en que yo también abjuré de mi sangre y [... . pretendí dejar atrás (olvidándola, aniquilándola) aquella sangre que para mí representaba no sólo la pobreza, la ignorancia y la superstición, sino también la fealdad, la derrota, el rencor y el odio, el lado oscuro y abyecto de la vida” (III 11). La incertidumbre de

${ }^{24}$ En este sentido, el motivo recurrente del aborto ha sido visto como una historia de resistencia femenina que viene desde los indios chalacos durante la invasión chilena cuando las "mujeres violadas por el enemigo provocaron abortos para resistir la invasión de su cuerpo”. También se considera aquí que Martín Villar rebate el estereotipo de la mujer sumisa y se ocupa de capacitar a Zoila Chira en el camino de una mujer liberada en el marco de una novela que aboga por los ideales de igualdad de raza y de género. Cfr. James Higgins, 102-104.

${ }^{25}$ El interés de Martín Villar por investigar el problema de las revoluciones en el mundo -al que nos referimos- surge a partir del triunfo de la Revolución cubana vivido con entusiasmo en sus años universitarios. La construcción de una nueva subjetividad aparece en El socialismo y el hombre en Cuba de Ernesto Che Guevara quien describe el hombre del mañana de la nueva sociedad comunista dueño de sí mismo y alejado de la enajenación del capitalismo. Este pensamiento trasciende la Cuba revolucionaria y amplía su visión al hombre universal en una colectividad armónica y solidaria. Véase Manuel Galich, 141.

26 Peter Elmore señala que "Martín Villar se propone culminar en dos sentidos la historia de los suyos: significativamente, la decisión de escribir el relato de la estirpe se complementa, de un modo estricto con la determinación de no engendrar descendencia” (634).

\footnotetext{
Sevista Iberoamericana, Vol. LXXX, Núm. 247, Abril-Junio 2014, 373-398 ISSN 0034-9631 (Impreso) $\quad$ ISSN 2154-4794 (Electrónico)
} 
un sujeto en busca de la armonía imposible, como señalaba Cornejo Polar, da cuenta de la fragilidad de una identidad en crisis. En esta perspectiva resulta esclarecedora la formulación de Paul Ricoeur en cuanto a las causas de la fragilidad de la identidad (110). En primer lugar, su difícil relación con el tiempo lo que justifica el recurso a la memoria, componente de la identidad, en unión con la evaluación del presente y la proyección del futuro. La segunda causa de fragilidad sería la confrontación con el otro sentida como una amenaza, de lo que deriva el rechazo o la exclusión. Y tercera: la herencia de la violencia fundadora, a la que hicimos referencia en la primera parte de este trabajo. Escribe Ricoeur: "Lo que celebramos con el nombre de acontecimientos fundadores son, en lo esencial, actos violentos legitimados después por un Estado de derecho precarios; legitimados, en definitiva, por su antigüedad misma, por su vetustez. De este modo, los mismos acontecimientos significan para unos gloria, y para los otros, humillación” (111).

Podríamos rastrear una conjunción de estas causas a lo largo del texto con un punto culminante en el epílogo de la novela, en el duelo verbal entre Martín Villar y su sombra: “¿Quién es este que habla?” (III 398) se pregunta el narrador, porque esta voz que ha encarnado las voces de sus antepasados y corresponde a un yo testimonial se ha venido desplazando constantemente hacia otro narrador más distanciado que refiere e interroga, en un vaivén constante del relato. A la operación del memorialista que desde el principio ha ido disociando la voz narrativa entre el sujeto que vivió los hechos y el que los recuerda ("recuperé la voz de mi padre al leer y releer con nuevos ojos los cuadernos que me legara” [I 39], dice el narrador protagonista), se agrega otra voz, la de un narrador ficcional que inmediatamente pregunta: "Pero, en fin ¿a qué hora murió el abuelo del pequeño Martín?”. El narrador-protagonista ya nos había advertido acerca "de un yo, cuya hipóstasis era mi propia sombra”, ${ }^{27}$ de un yo que fue avasallado por oscuridades, iluminaciones, silencios, enigmas y la ausencia del propio padre, y observaremos más tarde en el relato de formación del escritor cómo estas vivencias de una conciencia atormentada pugnan por transformarse por obra de la “oblicuidad sinuosa” (III 177) de la literatura. Es en el anteúltimo capítulo de la novela donde, del estallido de ese yo en "múltiples yoes" (III 179), emerge la sombra, el yo que lo ha acompañado desde el comienzo, un yo que parece confundirse con la voz del autor quien nos dice: "Véalo: este es Martín Villar, solo, derrotado y en un inquietante estado de apatía” (III 181). A través del diálogo, el escritor no solo confiesa a su doble las dudas sobre lo que va escribiendo, los cuestionamientos acerca de los posibles comienzos y finales de la novela, con transcripciones de algunos pasajes de la historia que ya conocemos, sino también se refiere a la lectura "de un oscuro simbolismo" que harían algunos críticos: “¿Te refieres a gentes como el cagón de Oviedo?” (III 185) responde la voz con quien

27 La cursiva corresponde al texto.

Revista Iberoamericana, Vol. LXXX, Núm. 247, Abril-Junio 2014, 373-398
ISSN 2154-4794 (Electrónico) 
él polemiza (tal vez el propio Gutiérrez), lo que hace pensar más directamente en los debates del campo literario que reseñamos en el comienzo de este trabajo.

Más allá de las referencias a la historia narrada interesan las consideraciones acerca de la utilización de ciertos recursos en la construcción del texto, en lo que se puede leer como una poética de la novela: además del manejo del suspenso en la ficción novelesca, los monólogos y leit motiv utilizados o descartados en algunos capítulos, al narrador Martín Villar le preocupa una cuestión central, la relación entre verdad y ficción o sea cuáles son los límites a la hora de comunicar una experiencia humana; cuestión sobre la que ya había manifestado su inquietud en otros pasajes de la novela: "me he repetido que no necesariamente coinciden las razones de la vida con las razones de la escritura" (II 249). De este reñido diálogo interesan algunas conclusiones a las que llega quien no es otro que el alter ego de Martín Villar señalando que "en el arte el camino equivocado conduce al fracaso y en la vida, de manera especial, elegir un camino equivocado resulta funesto, irreversiblemente funesto y condenable por las consecuencias que determina" (III 189, cursiva en el texto).

De este modo, el contrapunto entre la historia narrada y el relato sobre el proceso de la escritura plantea una tensión entre el testimonio y la ficción que nos conduce por las distintas líneas de fuga que va desarrollando el relato. Como los ríos de Piura que según el narrador-protagonista, algún geógrafo enumeró en tres: el río secreto, el normal y el furioso, vamos navegando por esas líneas del texto que parecen corresponder a las que Gutiérrez pensó para su novela:” reflexionar sobre el acto creativo artístico [...] narrar la historia secreta [...] y escribir un testimonio personal y familiar sobre la violenta década del 80 en que tuvo lugar la escritura de la novela” (“Sobre el rencor” 275).

En el final cobra relevancia la figura de Zoila Chira, maestra rural que al tomar conciencia de las luchas populares se confunde tal vez con la figura de Deyanira Uribarri, del homenaje primero, o con Vilma Aguilar, combatiente que aparece entre los reconocimientos del final. Lo cierto es que, de este modo, Gutiérrez nos recuerda la importancia fundamental de la participación de las mujeres en las filas de Sendero como podemos leer en el estudio sobre Sendero Luminoso de Carlos Iván DeGregori. ${ }^{28}$

28 "La participación femenina suscita una de las primeras reflexiones en las ciencias sociales peruanas sobre el papel de la mujer en los movimientos sociales. En efecto, Aracelio Castillo les dedica un subcapítulo de su tesis: 5.3. "Participación de la mujer”. Allí, entre alabanzas retóricas ["hijas de la heroína ayacuchana María Parado de Bellido”, “intrépidas!, ipertinaces!, ¡solidarias hasta el sacrificio!”] y citas de Lenin y Stalin, se reconoce a la mujer "como categoría independiente, como fracción de clase, como grupo social con características definidas", que tendría la posibilidad de "adquirir autodeterminación hasta ciertas fronteras, alcanzar el estatuto de verdadera categoría ontológica” y perfilarse: “como componente aparte dentro del complejo engranaje de las luchas populares”. El autor trata, además, de explicar las causas de esa singularidad femenina y esa combatividad “a veces más allá de la de los hombres”. Castillo reconoció la importancia de la mujer en su tesis. No fue el único. Paralelamente, otro protagonista del movimiento la comenzó a reconocer y asimilar a su manera a su práctica política. Era la "fracción

Revista Iberoamericana, Vol. LXXX, Núm. 247, Abril-Junio 2014,
ISSN 0034-9631 (Impreso) 
Ya en las escenas de la Comuna de París, el personaje de Baumant de Metz había hecho notar la presencia de mujeres combatientes de las clases medias que habían elegido el camino de la revolución popular.

La mujer, figura central de la historia narrada, cobra una vez más un relieve singular en el proceso de producción del texto -como señalamos-ya que el narrador-protagonista le confiesa a Zoila la necesidad de su lectura, de tener una perspectiva femenina acerca “de este sujeto que es Martín Villar” (III 259) aunque también reclama atención de otros lectores y hasta de un "hipotético e ¿hipócrita? lector del futuro” (II 73). Con su amigo Arturo Lama ha compartido el capítulo titulado "Fin de la Infancia” y le ha confesado sus dudas acerca de la derrota o la victoria (III 303) para concluir su novela, luego de conjurar sus fantasmas, en una escena en la que el narrador se identifica con Gregorio Samsa, el protagonista de La metamorfosis de Kafka, uno de los escritores favoritos de su período de formación.

Sin embargo, hay otro amigo a quien el narrador nombra como J.L. Díaz, sugestivamente con esas iniciales J.L., en una secuencia por la que desfilan desde Garcilaso y Guaman Poma hasta Brecht, Carpentier, Vallejo y el propio Jorge Luis Borges, ${ }^{29}$ configurando de este modo una escena de lectura crítica. Es un pasaje en el que J.L. nos devuelve una perspectiva que podemos pensarla en función de las filias y fobias del propio Gutiérrez, tal como aquel pasaje memorable del Primer diario de Arguedas $^{30}$ en su polémica con Cortázar acerca del escritor cosmopolita o regionalista. En una conversación de sagaz ironía (I 256-262), J.L. analiza una serie de cinco cuentos (luego “destruidos”) de la etapa de formación de Martín Villar, entre estos "Verdadera Relación de la Caída y Destrucción del Antiguo Perú”, y repasa su acercamiento, en realidad dice "plagios", al estilo erudito de Carpentier pero también a su imitación del marxismo de Brecht; le reprocha el empleo del monólogo interior al estilo joyceano para un personaje mestizo, y se refiere a Garcilaso y los Comentarios Reales como un "libro que si no fuera por su excelente prosa yo habría ordenado quemar, como destruían los incas toda memoria que resultaba perniciosa” (I 257). La mención de la prosa de

roja”, que poco después de los sucesos de junio conformaría el PCP-SL. Ya a inicios de la década de 1970 encontramos a sus dirigentes estudiando intensivamente el tema a nivel teórico y conformando, poco después, el denominado "Movimiento Femenino Popular" (128-130).

33 Ya desde el comienzo (I 154) encontramos una referencia a Borges en boca del famoso profesor Gandamo de la Romaña quien le observa a Martín Villar el uso del "calificativo tan borgiano [...] de 'conjeturable' que emplea usted para referirse a este linaje...”. También Gutiérrez en una entrevista se confiesa lector de Borges a quien tardó en valorar y como el autor que más lecturas permite. Véase Dante Dávila Morey, 315.

${ }^{34}$ Es muy conocido el pasaje del Primer Diario de El zorro de arriba y el zorro de abajo (Losada, 1971) en el que José M. Arguedas entabla un debate con Cortázar acerca del cosmopolitismo y regionalismo del escritor, sintiéndose parte de este último junto con Rulfo, más alejado de Carpentier o de Fuentes. Véase páginas 14-17.

Revista Iberoamericana, Vol. LXXX, Núm. 247, Abril-Junio 2014, 373-398 ISSN 0034-9631 (Impreso) ISSN 2154-4794 (Electrónico) 
Guaman Poma, un verso de Vallejo y la referencia al apellido indígena Lachira, de José Carlos Mariátegui, completan el cuadro de los escritores tutelares del narrador. ${ }^{31}$ Siempre en un tono burlón acerca de los "bodrios" que no debió haber escrito y refiriéndose a otro de los cuentos "Memorias del Cusco", J.L. añade que lo que pudo ser "una historia aceptable terminó siendo una farsa cruel, irreal y torpe”. Finalmente, Martín aclara que su intención fue "presentar la imagen del primer indio desarraigado, forastero en su propia tierra, a la vez apóstata y apátrida y fundador de la gran soledad y rencor que grava la conciencia del hombre peruano" (I 269), a lo que responde J.L con una cita de Gide: "con buenas intenciones se hace mala literatura".

La escena es reveladora en dos sentidos: no sólo porque revisa y pone en discusión un linaje y una concepción literaria con el recurso de autoridad en la velada figura de Borges, sino también porque remite a la crisis de identidad que venimos siguiendo en el texto en la que Gutiérrez pone de manifiesto tanto una preocupación nacional como un destino individual. ${ }^{32}$ En cuanto al primer aspecto se hace más evidente aquello que señalábamos respecto del desplazamiento de Gutiérrez en su itinerario de novelista crítico, porque esta escena de lectura en la que aparecen los nombres de Borges, Brecht, Joyce o Kafka, biblioteca en la que conviven junto a Mariátegui o Arguedas, exhibe y condensa la estructura quebrada de un relato que transgrede lo que sería propio del realismo socialista, la novela como totalidad y los personajes como arquetipos, argumento con el que se podría responder a la acusación reseñada acerca de un "concepto de la literatura anticuado" (véase página 5).

En segundo lugar, su recorrido por el tema de la identidad está muy lejos de un indigenismo de vieja estirpe y acercándose al pensamiento arguediano, parece plantear el complejo devenir del sujeto mestizo. En este sentido son ilustrativas las secuencias en las que el narrador relata su regreso al "hogar primordial" tras las huellas del agraviado linaje de los Villar y declara que "frente a este mundo que ya no era el suyo, se sintió forastero y lo fue avasallando un viejo sentimiento de orfandad". Podemos encontrar aquí otro punto de contacto con J. M. Arguedas en la figura del forastero que Cornejo Polar ("Heterogeneidad” 839) ha profundizado en lo que llamó la retórica del sujeto migrante. Sus rasgos de multiplicidad, inestabilidad y desplazamiento podrían seguirse a lo largo de la novela y observar la transformación que opera sobre la tradicional y conflictiva categoría de mestizaje. El diálogo polémico que encuadra esta secuencia finaliza cuando, luego de la fuerte interpelación de J.L., Martín Villar responde que sólo “escribió esas historias para matar el tiempo” (I 259); unas páginas más adelante en el

${ }^{31}$ En este sentido, los nombres de Pedro Asto (I 166) y Rosendo Maqui (III 376) podrían verse como un tributo a J. M. Arguedas y Ciro Alegría respectivamente, ya que provienen de sus novelas.

32 Pensamiento presente en el propio Gutiérrez quien con su ideario socialista, se ha manifestado acerca del respeto por el individuo. Véase Da Gama, 72.

Revista Iberoamericana, Vol. LXXX, Núm. 247, Abril-Junio 2014, $373-398$
ISSN 0034-9631 (Impreso) 
relato se ha deslizado la cita de Joyce "la historia es una pesadilla de la cual quisiera despertar” (I 133), que no solo parece conducir a la historia secreta del texto de Gutiérrez sino también al costoso devenir de la escritura para lograr el objetivo de la literatura: una posibilidad de vida. ${ }^{33}$

\section{CONSIDERACIONES FINALES}

Señala González Echevarría que lo más significativo de la novela latinoamericana es la negación de la literatura como su punto de partida (69). En la búsqueda del origen y la historia de una cultura dada viste disfraces para parecer otra cosa. Esta cualidad proteica es el fundamento de un subtexto determinado por el discurso novelístico en relación con otras formas no literarias de discurso. La ley en el período colonial, los escritos científicos en el siglo xIx y la antropología en el período moderno son los discursos hegemónicos con los que la narrativa entabla sus relaciones más productivas. Más recientemente, en lo que constituye la ficción del Archivo, la etnografía ofreció una manera de representar la originalidad de los relatos, de los que Cien años de soledad sería su manifestación más destacada.

Pero las novelas -añade González Echevarría- nunca se contentan con la ficción, tienen que pretender que aspiran a la verdad tras el discurso de la ideología que les da forma. Y la verdad de la que tratan es la propia ficción, lo que queda es el relato de la apertura del Archivo, ese archivo que guarda, retiene, acumula y clasifica. Estas consideraciones son las que me han permitido pensar La violencia del tiempo en ese registro que se profundiza y condensa en el epílogo.

El título "El rojo fuego de los médanos" se abre a un texto extraño al ritmo narrativo, una descripción del territorio de la tierra piurana como resultado de las revoluciones geológicas que determinaron su configuración. Desde las cumbres andinas, "una pura extensión en reposo absoluto” (III 352) pasando por el valle del Chira hasta llegar a los médanos candentes, la travesía de Martín Villar sigue “el inconcluso tratado” (III 361) de la Geografía física que el Dr. González dictara a su padre en los cuadernos que forman parte del Archivo. Paradójicamente esa vuelta a los orígenes para trazar la historia del linaje se presenta a través de una imagen del final del tiempo, "estamos ante un espacio muerto, de hervores sofocados, como el de la luna, como los paisajes del alma”-piensa

${ }^{37}$ En la función fabuladora de la literatura se presenta, para Deleuze, una iniciativa de salud que consiste en el paso de la vida al lenguaje a través de visiones y audiciones que hemos visto dramatizadas y constantemente tematizadas en esta novela (15). La función fabuladora de la literatura consiste en inventar un pueblo que falta: "Tal vez sólo exista en los átomos del escritor, pueblo bastardo, inferior, dominado, en perpetuo devenir, siempre inacabado. Un pueblo en el que bastardo ya no designa un estado familiar, sino el proceso o la deriva de las razas". Y esto con el trabajo sobre el lenguaje llevado al límite por un narrador-autor que se ha propuesto "devenir otra cosa que escritor".

Revista Iberoamericana, Vol. LXXX, Núm. 247, Abril-Junio 2014, 373-398
ISSN 0034-9631 (Impreso) 2154-4794 (Electrónico) 
Martín Villar- y en detalles minuciosos, el narrador explora la naturaleza tratando de descifrar los secretos lenguajes de la tierra, las aguas, los vientos y los fuegos del sol.

De este modo, la ficción del archivo al tratar del origen toma la forma de un mito moderno, no sólo por las referencias a la atmósfera natural antes señaladas, sino también por el recurso a las figuras dotadas de significado fundador. En este sentido se pueden considerar los escritos de Juan Evangelista Chanduví Mechato con su Libro de la Comunidad otro de los paradigmas, junto al Dr. González, de esta "tortuosa, desmesurada ficción” (III 382). El narrador-protagonista descubre en el apellido Lachira (ya mencionado con referencia a Mariátegui) un ancestro común con este descendiente de curacas desposeídos de sus dominios, "aunque la sangre suya padezca el escarnio del mestizaje -le dice Chanduví- que alimenta quimeras y soberbias y pretensiones insignificantes y utópicas, pero que dejan en el alma las cenizas de la orfandad y la sal y el vinagre del destierro, y no hay abrevadero para esta sed" (I 285). Es en aquel Libro de la comunidad, el libro perpetuo donde cada generación escribe su resistencia y lucha contra el ultraje y la opresión, libro de los pueblos contra el olvido donde Martín Villar quisiera que su ficción tuviera un capítulo, como una manera de desafiar "la precariedad de la existencia que se fundara en la transitoriedad irracional de la historia” (III 345).

En el pasaje de uno a otro texto -de la Geografía física al Libro de la comunidad-(o entre el espacio y el tiempo), el narrador recuerda un verso de Vallejo que significativamente es el epígrafe de la novela "Los pilares que vi me están oyendo"; colocado en el final este verso parece otorgar una circularidad o unidad de sentido a un texto que permanentemente va huyendo de los límites, a la luz de esta fábula de desplazamiento de la literatura. Porque otras líneas de fuga abrirán ese sentido que exhibe su cualidad de incompletud y multiplicidad. Así la indagación filosófica que enmarca la reflexión acerca del luto y la muerte en su vínculo con la escritura, amparada en la Ética de Spinoza, emerge de la historia de vida del Dr. González, el papá-doctor, figura con la que el protagonista manifiesta su identificación: "Las consideraciones del Dr. González las sintió como propias, como si él las hubiera escrito, pues de manera lúcida y racional expresaban un pensamiento oscuramente sentido...” (III 369). Se agrega esta afinidad a la condición múltiple de un sujeto cuyo estallido veníamos señalando en el transcurso del relato, sobre todo en la superposición de la voz del narrador ficcional, la sombra que acompañó a Martín desde el comienzo y que se hace ahora más palpable en este final, cuando asume la primera persona para preguntarse quién fue, quién es Martín Villar. Ese narrador es quien nos informa acerca de la afinidad de "nuestro héroe" con quien "tuvo la finura de acabar por sí mismo con su vida cuando supo que toda lucha estaba condenada a una nueva derrota y a la inútil prolongación de la agonía” (III 353). Entremedio de pasajes luminosos por la geografía del lugar y las meditaciones filosóficas, nos sorprende la descripción del suicidio programado por el Dr. González, de una rutina con precisión de

\footnotetext{
Revista Iberoamericana, Vol. LXXX, Núm. 247, Abril-Junio 2014, 373-398 ISSN 0034-9631 (Impreso) ISSN 2154-4794 (Electrónico)
} 
días y horas para que no fuera un acto desesperado e irracional. Y no podemos dejar de evocar nuevamente la figura de Arguedas con el mismo final para su novela testimonial.

Al detenernos en la lectura que hace Martín de las "anotaciones marginales" (III 365) del Dr. González tomadas aquí y allá no sólo de la Ética sino también de De rerum natura de Lucrecio, los Pensamientos de Pascal y los Cantos de Leopardi que eran sus libros de cabecera, observamos que se destacan aquellas referidas al cosmos, la naturaleza como escenario del drama del amor y el luto humano como sustancia de la vida, reflexiones vinculadas con la experiencia del papá-doctor que parecen provenir de la propia vida de Martín Villar. El recuerdo de sus últimas vivencias en la casa de Lima se enlaza con las distintas muertes mientras va "navegando aguas arriba del tiempo" y se pregunta “¿Imaginar, escribir, protegerían a su cuerpo de la fascinación que aún sentía por la muerte?” (III 375). Con el espíritu de la duda que lo atenaza, Martín Villar imagina distintas alternativas para el final de la historia que el narrador ficcional, en un pliegue más de este texto transcribe a modo de cita, destacándose del secreto misterio de las incontables páginas escritas, el primer final que debía llevar el nombre "Evocación de Deyanira Uribarri”. Mientras el protagonista finalmente sale de su madriguera, refugio de lectura, y vuelve a su travesía por el desierto "en busca de una imagen perdida” (III 396), a merced de las turbulentas voces que se (lo) siguen interrogando acerca de la travesía de la escritura, la mención de esta figura nos devuelve al homenaje primero y con él al testimonio personal del escritor. De modo tal que la historia narrada al vincularse con el acontecimiento real de la violencia de los ochenta a través del testimonio, lleva las huellas de las relaciones entre los libros y la vida, entre las armas y las letras y nos plantea una vez más la complejidad del vínculo historia y ficción.

En La violencia del tiempo la fuerza totalizadora del Archivo que lo contendría todo está muy presente pero además su espaciosidad e incompletud se materializa e intensifica en esa imagen final de un desierto ordenado "según el estricto y hermético derrotero impuesto por los vientos” (III 358), lo que también refiere a la figura del final del tiempo, final de la historia. Como hemos podido ver el curso del tiempo que ha seguido el narrador al tratar de reconstruir la historia, internándose por zonas oscuras e impenetrables refiere a una concepción alejada de la linealidad y unidad del tiempo histórico, y nos recuerda el pensamiento de Walter Benjamín quien en su tesis 6 escribe: "Articular históricamente lo pasado no significa conocerlo 'tal y como verdaderamente ha sido'. Significa adueñarse de un recuerdo tal y como relumbra en el instante de peligro" (180). Sin duda es posible pensar la investigación del pasado que lleva adelante Gutiérrez desde la intensidad que ha desencadenado ese recuerdo de una vivencia cercana y al trabajo de rememoración como un proceso de "confrontación de la heredad del pensamiento del pasado” (Vattimo 29). En esa confrontación Gutiérrez transmite sentimientos contradictorios que merodean la utopía y el desencanto, que si, por un lado, enfrentan la experiencia histórica desde una resistencia que en cada coyuntura

\footnotetext{
Revista Iberoamericana, Vol. LXXX, Núm. 247, Abril-Junio 2014, 373-398 ISSN 0034-9631 (Impreso) ISSN 2154-4794 (Electrónico)
} 
actualizaría la violencia latente en la sociedad (presente desde el comienzo en Deyanira Uribarri como una “justiciera Antígona”), por otro, el devenir de esa historia sólo da lugar a la pérdida y la aceptación de la derrota. Esta contradicción es llevada al límite en el final de la novela que se puede leer como un interrogante acerca de la pérdida de fe del escritor en su anhelo por la creación de un "grandioso metarrelato político- cultural” (González Echevarría 240) que ya no puede aspirar a ser una fábula de fundación. En cambio, parece abismarse en los caminos de la incertidumbre que, paradójicamente, potencian sus lazos con la imaginación y el arte de la novela, como el camino trazado para su protagonista: "Reivindicación de un linaje humillado, retorno a la comunidad y consolación por la literatura: he aquí el camino de perfección de Martín Villar” (III 310).

En este sentido, es posible pensar La violencia del tiempo en la línea de lo que Ángel Rama llamó una literatura de derrotados que "no es forzosamente una renuncia al proyecto transformador, sino un paréntesis interrogativo que permite avizorar los conflictos en su mayor latitud" ("Riesgosa navegación” 13). Prueba de ello no son únicamente las convicciones políticas y éticas de Gutiérrez que hemos podido leer en la línea del ensayo y en algunas entrevistas, ${ }^{34}$ sino también la continuidad de su camino en la narrativa de sus producciones ${ }^{35}$ posteriores.

\section{BiBLIOGRAFÍA}

Abanto Aragón, David. “Grupo Narración: La Redención a través del compromiso”. Prólogo a Néstor Tenorio Requejo. El grupo Narración en la literatura peruana. Lima: Arteidea Editores, 2007.

Agreda, Javier. “Jaque perpetuo. Miguel Gutiérrez y la generación del 50”. 14 julio 2008. <www.larepublica.pe>.

Ainbinder, Eduardo. “El narrador de las cantinas”. Entrevista a Oswaldo Reynoso. N, Revista de cultura 318 (2009): 22.

\footnotetext{
${ }^{34}$ En una entrevista titulada "El partido del novelista es el de la novela", Gutiérrez hace referencia a que "Los acontecimientos que han ocurrido en el mundo, en el Perú, obviamente nos llevan a replantear algunos problemas. Uno puede replantearse algunas cosas en el nivel de la teoría, en el nivel de la línea política, pero hay algo que antecede a esta teoría, que ha sido el partido que tú has tomado en la vida por la gente de tu país” (Tumi 371), y en otra: “Aún cuando ahora el mundo ha cambiado y los vientos son otros (por lo menos temporalmente) sigo raigalmente comprometido con el mundo popular” (Da Gama 72).

35 Entre otras publicó la novela Babel, el paraíso (1993) luego de una permanencia de tres años en China donde vivió una experiencia con grupos marxistas maoístas que luchaban por establecer hegemonías, de los que se sintió marginal y casi desencantado porque las convicciones ideológicas pasaban por encima de la condición humana (véase Da Gama 68). De esta novela declara que tiene la forma de una parábola kafkiana, una abstracción inspirada en la China en un momento que coincidía con el hundimiento del mundo socialista y la derrota de la guerra subversiva en el Perú (véase Ledgard 348).
}

Revista Iberoamericana, Vol. LXXX, Núm. 247, Abril-Junio 2014, $373-398$
ISSN 0034-9631 (Impreso) 
Arguedas, José María. El zorro de arriba yel zorro de abajo. Buenos Aires: Losada, 1971. Benjamin, Walter. “Tesis de Filosofía de la Historia”. Discursos Interrumpidos. Madrid: Taurus, 1973. 177-191.

Cornejo-Polar, Antonio. "Literatura peruana eidentidad nacional: tres décadas confusas". Perú 1964-1994: Economía, sociedad y política. Julio Cotler, ed. Lima: Instituto de Estudios Peruanos, 1995. 293-302.

"Una heterogeneidad no dialéctica: sujeto y discurso migrantes en el Perú moderno”. Revista Iberoamericana LXII/176-177 (1996): 837-844.

Da Gama, Francisca. Entrevista. Miguel Gutiérrez. Hispamérica XXIX/87 (2000):65-80.

Dávila, Dante. “Conversaciones con Miguel Gutiérrez”. Del Viento, el Podery la Memoria, Materiales para una lectura crítica de Miguel Gutiérrez. Cecilia Monteagudo y Víctor Vich, eds. Lima: Pontificia Universidad Católica del Perú, 2003. 309-333.

Degregori, Carlos Iván. “¿Por qué apareció Sendero Luminoso en Ayacucho? El desarrollo de la educación y la generación del 69 en Ayacucho y Huanta”. Historizar el pasado vivo en América Latina. Anne Pérotin-Dumon, dir. <www.Historizarelpasadovivo. $\mathrm{cl} / \mathrm{es}>$. (2007).

Deleuze, Gilles. "La literatura y la vida”.Crítica y clínica. Barcelona: Anagrama, 1996.11-18.

Elmore, Peter. "La sangre y la letra: los modos de filiación en La violencia del tiempo de Miguel Gutiérrez”. Revista Iberoamericana LXXIII/220 (2007): 631-648.

Enríquez, Mariana. “Elmarxista rabioso”. Radar Libros, Página 12. 3 mayo 2009.<http:// www.pagina12.com.ar/diario/suplementos/libros/10-3429-2009-05-03.html>.

Galich, Manuel. “Che: encarnación del hombre nuevo”. Casa de las Américas VII/46 (1968):140-143.

Godos Curay, José Miguel. "La toma de Piura por los chalacos: un acontecimiento político y social”. El Regional de Piura. 30 ago. 2011. <puropiura.blogspbt.com>.

González Echevarría, Roberto. Mitoy archivo. Una teoría de la narrativa latinoamericana, México: Fondo de Cultura Económica, 2000.

Gutiérrez, Miguel. La violencia del tiempo. Lima: Milla Batres, 1991. Prólogo a la segunda edición .La generación del 50: un mundo dividido, 20 años después. <www.zonadenoticias.blogspot.com> 21 julio 2008.

"Sobre el rencor y la furia de los Villar" . Bull. Inst. fr. Études andines, 28/2 (1999): 275-279.

Higgins, James. "Replanteando las relaciones de raza y género en el Perú: La violencia del tiempo de Miguel Gutiérrez”. Del Viento, el Poder y la Memoria, Materiales para una lectura crítica de Miguel Gutiérrez. Cecilia Monteagudo y Víctor Vich, eds. Lima: Pontificia Universidad Católica del Perú, 2003. 90-105.

Klaren, Peter F. “'El tiempo del miedo’ (1980-2000), la violencia moderna y la larga duración en la historia peruana”. Historizar el pasado vivo en América Latina. Anne Pérotin-Dumon, dir. <www.historizarelpasadovivo.cl/es> (2007).

Revista Iberoamericana, Vol. LXXX, Núm. 247, Abril-Junio 2014, 373-398 ISSN 0034-9631 (Impreso) $\quad$ ISSN 2154-4794 (Electrónico) 
Ledgard, Melvin. "Miguel Gutiérrez, un profeta en su tierra”. Del Viento, el Poder y la Memoria, Materiales para una lectura crítica de Miguel Gutiérrez. Cecilia Monteagudo y Víctor Vich, eds. Lima: Pontificia Universidad Católica del Perú, 2003. 334-353.

Lienhard, Martin. La voz y su huella. La Habana: Casa de las Américas, 1990.

Manrique, Nelson. Introducción. El tiempo del miedo. La violencia política en el Perú 1980-1996. <www.ciberayllu.org> (2002).

Nitschack, Horst. "Miguel Gutiérrez - la violencia de la historia: olvidar y recordar". Del Viento, el Poder y la Memoria, Materiales para una lectura crítica de Miguel Gutiérrez. Cecilia Monteagudo y Víctor Vich, eds. Lima: Pontificia Universidad Católica del Perú, 2003. 126 -152.

Oviedo, José Miguel. "Literatura Hispanoamericana. Dentro y fuera del canon”. El Dominical. 17 ago. 2008. <www.elcomercio.pe>.

Pérotin-Dumon Anne. Introducción. Historizar el pasado vivo en América Latina. Perú veinte años de violencia reciente. <www.Historizarelpasadovivo.cl/es> (2007).

Rama, Ángel. La ciudad letrada. Hanover: Ediciones del Norte, 1984. "La riesgosa navegación del escritor exiliado". Nueva sociedad 35 (1978): 5-15.

Reynoso, Oswaldo. En octubre no hay milagros. Buenos Aires: El Andariego, 2009.

Richard, Nelly. "La cita de la violencia: convulsiones del sentido y rutinas oficiales". Punto de Vista 63 (1999): 26-33.

Ricoeur, Paul. La memoria, la historia y el olvido. Buenos Aires: F.C.E., 2004.

Sen, Amartya. Identidad y violencia. Buenos Aires: Katz, 2007.

Thays, Iván. "Un artefacto literario anacrónico. Miguel Gutiérrez y un mundo dividido”. El Dominical. 3 ago. 2008. <www.elcomercio.pe>.

Sodré, Muñiz. Sociedad, cultura y violencia. Buenos Aires: Norma, 2001.

Todorov, Tzvetan. Los abusos de la memoria. Barcelona: Paidós, 2000.

Torre, María Elena. "Cuerpos de la violencia. Literatura y política en Alonso Cueto”. Actas del VII Congreso Internacional Orbis Tertius de Teoría y Crítica Literaria. $<$ http://www.orbistertius.unlp.edu.ar/congresos/viicitclot/Actas> (2009).

"Senderos de la narración: entre Alonso Cueto y Santiago Roncagliolo". Actas del III Congreso Internacional "Transformaciones culturales: Debates de la teoría, la crítica y la lingüística” (2008).

Tumi, Francisco. "El partido del novelista es el de la novela". Del Viento, el Poder y la Memoria, Materiales para una lectura crítica de Miguel Gutiérrez. Cecilia Monteagudo y Víctor Vich, eds. Lima: Pontificia Universidad Católica del Perú, 2003. 354-374.

Vattimo, Gianni. Ética de la interpretación. Buenos Aires: Paidós, 1992.

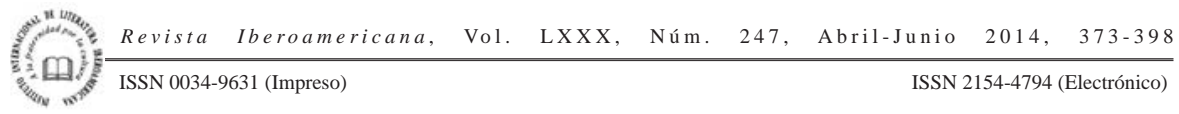

